\title{
A Primer on Exporting to Nicaragua ${ }^{1}$
}

\author{
Christina D. Storz, Timothy G. Taylor, and Gary F. Fairchild ${ }^{2}$
}

\section{Introduction}

Every year the U.S. Department of State publishes extensive Country Commercial Guides for a large number of countries. These guides provide a great deal of information useful to individuals interested in developing export markets either through direct exports or through direct foreign investment. This paper provides an abridged version of the Country Commercial Guide for Nicaragua as well as supplemental information of direct relevance to agribusiness firms. It is hoped that the information contained in this report provides a useful starting point for individuals interested in exploring export or investment opportunities in Nicaragua.

Note: County Commercial Guides are available for U.S. exporters from the National Trade Data Bank's CD-ROM or via the Internet. Please contact Stat-USA by telephone (1-800) STAT-USA for more information. Country Commercial Guides can be accessed via the World Wide Web at http://www.stat-usa.gov, http://www.state.gov, and http://www.mac.doc.gov. They can also be ordered as a hard copy or on diskette from the National Technical Information Service (NTIS) by telephone (1-800) 553-NTIS. American exporters seeking general export information/assistance and country-specific commercial information should contact the U.S. Department of Commerce, Trade Information Center by telephone (1-800) USA-TRADE; or by fax (202) 482-4473.

\section{Economic and Political Overview}

Nicaragua is one of the world's most indebted countries on a per capita basis. It is highly dependent on foreign donations and remittances. Nicaragua is negotiating an IMF program to reduce its US\$6.3 billion external multilateral and bilateral debt under the Heavily Indebted Poor Countries (HIPC) initiative. To do this, the Bolaños administration needs to produce a plan for fiscal reform, show progress on the liquidation of Central Bank assets, and deal with Nicaragua's internal debt crisis. Forecasts of real GDP (Gross Domestic Product) growth in 2002 range from $1 \%$ to $2 \%$.

Nicaragua's economy grew by $3 \%$ in 2001 , slower than the $4 \%$ growth in 2000 . The lower growth rate primarily reflected the steady decline in prices for Nicaragua's main export commodities, especially coffee, as well as the failures of four national banks in one year and uncertainty surrounding the November 2001 presidential elections. In 2001, the GDP reached US $\$ 2.24$ billion. Tourism, agriculture, construction, mining, telecommunications, and

1. This is EDIS document FE518, a publication of the Department of Food and Resource Economics, Florida Cooperative Extension Service, Institute of Food and Agricultural Sciences, University of Florida, Gainesville, FL. Published February 2005. Please visit the EDIS website at http://edis.ifas.ufl.edu.

2. Christina D. Storz, Research Assistant; Timothy G. Taylor, Professor; and Gary F. Fairchild, Professor, Department of Food and Resource Economics, Florida Cooperative Extension Service, Institute of Food and Agricultural Sciences, University of Florida, Gainesville, FL. 
commerce are expected to be the principal growth sectors over the next few years. Private investment, both local and foreign, has declined, falling from US\$300 million in 1999 to US\$110 million in 2001. As a result of continued high population growth, GDP per capita grew by only $0.01 \%$ in 2001 to an estimated US\$460.

In 2001, the primary sector (including farming, livestock, fisheries and forestry) accounted for $30 \%$ of Nicaragua's GDP, over $68 \%$ of exports, and $44 \%$ of labor generation. The agricultural sector grew by $2.3 \%$ in 2001, down from an $11 \%$ growth in 2000 . Although the volume of several key commodities was near record levels, low commodity prices (especially for coffee) largely deflated the agricultural sector. The Nicaraguan government, as well as the international donor community, has placed great emphasis on agricultural reactivation. Farming grew by $7.7 \%$ in 2001 , down from $13.2 \%$ in 2000 . Meat was the only agricultural commodity whose price remained constant while its production volume increased. Exports of slaughtered animals increased $9 \%$, and exports of live animals increased $7 \%$. Fishing decreased $10 \%$ in 2001, down from a $14 \%$ increase in 2000. Nicaragua's low population density and ample grazing land offer future potential for further expansion of the livestock sector.

Nicaragua is essentially an agricultural economy with a small manufacturing base. It is dependent on imports for most manufactured, processed, and consumer goods. In recent years the government has liberalized the foreign trade regime, sharply reduced tariffs, and eliminated most non-tariff barriers and foreign exchange controls.

The United States remains by far Nicaragua's largest trading partner. Two-way trade in 2001 totaled US\$975 million, of which US\$609 million were Nicaraguan exports and US\$366 million were U.S. exports. These figures have risen steadily in recent years and are expected to continue to do so. Nicaraguan consumers maintain an evident preference for American products and U.S.-style services.

The best prospects for U.S. sales include agricultural commodities, fertilizer, farm equipment, food processing/packaging machinery, medical supplies, data processing equipment, electrical equipment, franchising, construction equipment, and motor vehicles and spare parts. Investment opportunities exist in export-oriented manufacturing, tourism, mining, and agriculture. Opportunities also exist in road building, water system construction and management, telecommunications, and electricity generation.

\section{Marketing U.S. Products and Services}

There are a number of factors that should be considered in exporting products to Nicaragua. This section provides a brief overview of many critical factors that must be considered.

\section{Establishing a Business}

There are various ways to establish a business in Nicaragua. The two most common are as a sole proprietorship or as a corporation. The basic steps for organizing a business are as follows:

- Register and incorporate the business at the Ministry of Finance (Ministerio de Hacienda y Crédito Público). After paying the registration fees, a tax identification number must be acquired (note: if incorporating, a notarized letter from the corporation's board of directors authorizing incorporation in Nicaragua is required).

- Register with the Office of the Mayor of the Department where the business is located. At this office, the new business may elect to pay a fixed tax quota on sales or contract an accountant to maintain detailed records. If the accountant option is chosen, the books must be registered with the Ministry of Finance's Office of Fiscal Records.

In addition to these steps, other permits/licenses may be required depending on the business in question. We recommend the retention of an experienced commercial attorney for any investor interested in establishing an operation in Nicaragua. 


\section{Distribution / Sales Channels}

Local distributors and agents handle distribution and sales of imported products. The Nicaraguan retail market is small though expanding.

\section{Agents / Distributors: Finding a Partner}

The May 1997 retroactive tax reform legislation abolished the law on local agents and distributors, whereby the interests of these parties were afforded considerable protection and the termination of such a relationship could prove costly. Currently, contracts are based solely on party mutual consent. Nevertheless, contracts in effect prior to the May 1997 tax reform legislation remain valid.

Partnerships between U.S. and Nicaraguan businesses are common. There is no clearinghouse of information for finding a partner in Nicaragua. It is recommended that U.S. companies seeking agents, distributors, or partners in Nicaragua either purchase the International Partner Search (IPS) from their nearest U.S. Department of Commerce District Office or contact the Commercial Section of the U.S. Embassy in Managua, the Nicaraguan Center for Export and Investment (CEI), and/or local business chambers.

\section{Direct Marketing}

There is little direct marketing in Nicaragua at the present time. No specific law or regulation governs the field. Obstacles to profitable direct marketing include an unreliable postal service, inconsistent treatment of goods at Customs, and the lack of an efficient delivery system.

\section{Franchising}

Nicaragua has no specific law regulating franchises. Prospective franchise proprietors must follow the general regulations concerning foreign investment and starting a business contained in the Commercial Code and Foreign Investment Law. The franchise market for Nicaragua is booming, particularly for fast food. According to the Nicaraguan Tourism Institute, projected investment in fast-food restaurants in Nicaragua is an estimated US\$21 million.

\section{Joint Ventures / Licensing}

The Commercial Code governs all types of business organizations. The code permits joint ventures, license arrangements, general and limited partnerships, and corporations. Foreign investors are generally accorded national treatment under the Commercial Code.

\section{Selling Factors / Techniques}

Sales and marketing techniques in Nicaragua are increasing in sophistication. Most advertising takes place via radio, newspapers, television, Internet, and billboards. Trade fairs and industry-specific shows have become more frequent in the past few years. Companies are adopting more modern marketing techniques such as door-to-door advertising and special sales promotions. Marketing advances are due to Nicaragua's economic growth and liberalization, the greater availability of financing, and a larger selection of goods.

\section{Advertising / Trade Promotion}

Most business advertising and trade promotion in Nicaragua is conducted through the print media. There are a few regularly scheduled trade shows in Nicaragua. Trade events are usually held at the Hotel Intercontinental Managua Convention Center or the Olof Palme Convention Center in Managua.

\section{Sales Service / Customer Support}

Most local businesses place little emphasis on sales service and customer support. American and foreign businesses that have made customer service a priority have been well received.

\section{Product Pricing}

There are no price controls with the exception of controls on pharmaceutical sales margins, sugar, domestically produced soft drinks, national cigarettes, and liquefied natural gas.

\section{Selling to the Government}

Nicaragua's law on Government Procurement went into effect in January of 2000. This law regulates all government purchases except for certain acquisitions by the Ministry of Defense and the 
National Police on the grounds of national security. Purchases even partially financed by loans or grants from foreign governments or international organizations are conducted according to the procedures of the financing organization. To participate in any government procurement one must first register with the government's Suppliers' Registry at the Ministry of Finance. Within the first month of every fiscal period every agency or ministry subject to the present law must publish a calendar of bids projected for that fiscal period, with detailed information on the type of services to be acquired, projects to be performed, and material or equipment to be purchased.

\section{IPR Infringement Protection}

Patent applications must be filed with the Ministry of Development, Industry and Trade (MIFIC) at the Intellectual and Industrial Property Registry. Fees are $\$ 200$ for applying. Both parties determine an examination fee. Fees range from US $\$ 50$ for the first six years to US\$600 for a 20 -year license. On average, there is a minimal six-month delay for issuance. Protection is granted for 20 years from the date of application.

Copyright applications must also be filed with the Intellectual and Industrial Property Registry at MIFIC. There is a US\$10 information service fee, a US $\$ 40$ registration fee, a US\$70 fee for phonograms, a US $\$ 100$ fee for computer software, and a US\$20 fee for registration of contracts. Registration forms cost US\$2 each, audiovisual applications cost US $\$ 70$ each, and photography costs US\$20. There is a one-month delay for issuance. The protection granted is for the lifetime of the author and up to 70 years of the lifetime of his/her heirs.

Trademark applications must be filed with the Intellectual and Industrial Property Registry at MIFIC. There is a US\$50 charge to publish the trademark in the government gazette and, on average, a six to nine month delay for issuance. The applicant must present a sample of the trademark for which protection is being requested with the application.

Intellectual property rights protection in Nicaragua does not meet international standards, although there has been considerable progress over the past several years. The government still must develop a credible enforcement regime.

\section{Need for a Local Attorney}

Local attorneys are recommended for all business activities. There are numerous law firms in Managua with experience in international business and with English-speaking attorneys on staff.

\section{Agribusiness Industry Prospects}

In 2001, the agricultural sector, consisting of traditional agriculture, livestock, fisheries, and forestry, represented $30 \%$ of Nicaragua's GDP. The sector grew $2.3 \%$ in 2001, after growing by $10.6 \%$ in 2000. Reasons for the slower growth include the drop in international coffee prices; declines in the prices of sugar, bananas, and other products; and investment disputes among shrimp farmers.

In the area of U.S. government sponsored credit, USDA offers the GSM-102 and GSM-103 and Facility Guarantee Credit Programs through local banks, BAC, and Bancentro. American agricultural commodities that qualify for this credit include, but are not limited to, feed grains, seed, semen, live animals, wood, and rice. Also available is the Supplier Credit Program, whereby USDA approved exporters can offer insured credit to Nicaraguan importers. From time to time, USAID offers credit through local channels to Nicaraguan farmers.

\section{Wheat}

In 2001, U.S. exports of wheat to Nicaragua totaled US\$12.7 million. Three private mills export wheat to Nicaragua from the United States. Nicaragua imports primarily spring wheat and small quantities of soft wheat and hard red wheat.

\section{Rice}

\section{Consumer-Oriented Agricultural Prodcuts}

In 2001, U.S. exports of consumer food products reached US\$20.5 million. This included snacks, breakfast cereals, spices, red meats (fresh/chilled/frozen), juices, dairy products, processed fruits, processed vegetables, wine, and beer. In 2000, imports of this nature were in the same range. 


\section{Oils}

In 2001, U.S. exports of vegetable oil to Nicaragua totaled US\$14.7 million. Some US\$7.4 million of this amount was soybean-based. Nicaragua also imports soybean oil from Argentina, palm oil from Malaysia, and palm oil (stearin) from Honduras.

\section{Tallow}

In 2001, U.S. exports of animal fats to Nicaragua totaled US $\$ 3.1$ million. Nicaragua produces only about 2,800 metric tonnes (MT) of tallow per year and normally consumes $17,000 \mathrm{MT}$ to $19,000 \mathrm{MT}$.

\section{Agro-Chemicals}

In 2001, the Central Bank of Nicaragua reported overall agro-chemical imports of US $\$ 5$ million. This is a significant drop compared to 2000, when reported imports were US\$39 million. This decline may be attributed largely to the drop in coffee prices, which has discouraged coffee growers from investing in their farms. The main chemicals used in recent years include nitrogen, fungicides, herbicides, and compound formula fertilizers. The main countries that export chemicals to Nicaragua include the United States, Europe, and other Central American countries.

\section{Soybean Meal}

In 2001, Nicaragua imported US\$5.2 million of soybean meal from the United States, compared to US\$5.3 million the previous year.

\section{Poultry / Livestock Genetics}

In 2001, U.S. exports of hatching eggs to Nicaragua reached US\$4.4 million, compared to US $\$ 4.3$ million the previous year. The growing Nicaraguan poultry meat industry, high-quality U.S. genetics, and adequate incubator space have led to increased poultry genetics imports, mostly from the United States. In 2001, the country imported approximately US\$280,000 in cattle from the United States. Future livestock imports will depend on price and credit terms as well as beef prices. The U.S. Department of Agriculture's GSM-102/103 and Supplier-Credit programs are available to support related imports, and have already been used by several Nicaraguan importers.

\section{Yellow Corn}

American exports to Nicaragua were approximately US\$23 million in 2001. This is a significant increase over the last three years, which had average imports of US\$2.9 million.

\section{Trade Regulations and Standards}

\section{Trade Barriers}

Nicaragua's current tax law is an important tool in fostering investment in Nicaragua. Currently, almost all non-trade barriers on imports are banned. There is an established "rebate" of $1.5 \%$ of FOB value for all exports. Municipal taxes have been reduced to $1 \%$ and income tax on interest and capital gains stemming from transactions on the local stock exchange have been eliminated. In April of 2000, the National Assembly modified the Law to reduce nominal luxury (IEC) taxes and to extend benefits enjoyed by cooperatives and the small business, agricultural, aquaculture and fishing sectors. Importers of most items face a total import tax burden of $20 \%$ to $68 \%$. The tax law (Ley de Justicia Tributaria), which covers import tariffs, has been modified several times. In the 1990s, Nicaragua had lowered its import tax levels to the lowest in Central America. In response, Nicaragua's Central American Common Market partners asked it to raise its import tariffs, which it did in May of 2001. Nicaragua levies a 15\% import tariff on 1257 intermediate goods produced in Central America and a 5\% tax on intermediate goods imported from outside, but still assembled and produced in, Central America. The import tariff (DAI) is $30 \%$ for whole chickens, chicken cut into parts, and chicken breasts); $170 \%$ percent for chicken thighs and legs; and $15 \%$ for water, soft drinks, alcoholic beverages, cigars, and cigarettes. Nicaragua has eliminated its ATP (temporary protective) tariff for capital and intermediate goods. Some finished goods will continue to be levied an ATP of 5\%. The DAI and the ATP are based on CIF value of the product imported.

A luxury tax is levied through the specific consumption tax (IEC) on 609 items. The tax generally is lower than $15 \%$ (with significant exceptions). The IEC for domestically produced goods are based on the manufacturer's price and the 
IEC for imported goods are based on CIF, except for alcoholic beverages and tobacco products, in which case the IEC is assessed on the price charged to the retailer. The IEC on soft drinks will decrease by three percentage points annually until it reaches $9 \%$. The IEC levied on alcoholic beverages are between 34\% and $43 \%$. The IEC on rum and other liquor, currently $37 \%$, will decrease until it reaches $35 \%$. The IEC on beer, currently $34 \%$ to $37 \%$, will fall by one percentage point annually until it reaches $32 \%$. In terms of imported alcoholic beverages and tobacco products, the tax is now based on the sales price to the retailer rather than on the CIF price. The IEC on cigars and cigarettes decreased to 40\% in April 2001, and will decrease by one percentage point annually until the tax reaches $38 \%$.

Nicaragua levies a $15 \%$ value-added tax (IGV) on most items except agricultural inputs. Import duties on "fiscal" goods (e.g., tobacco, soft drinks, and alcoholic beverages) are particularly high. Some protected agricultural commodities (e.g., corn and rice) face tariffs near $100 \%$.

\section{Customs Valuation}

Foreign investors have, in the past, complained about arbitrary Customs procedures and valuations. Tariffs and import taxes for most used goods are not assessed on a CIF/bill of lading basis, but rather on a "reference price" determined by Customs at the time of entry inspection. This reference price can be significantly higher than the actual amount paid by importers. The presentation of a bill of sale (or other evidence of purchase price) that is certified by a Nicaraguan consular official is often, but not always, accepted by Customs inspectors as proof of the value of used goods. Nicaragua is behind schedule on the implementation of the World Trade Organization's (WTO) Customs Valuation Agreement (CVA).

\section{Standards}

Official standards are not in place for manufactured and processed products. However, standards issued by the Central American Institute of Industrial Research and Technology are often used as a guide.

\section{Labeling Requirements}

The Consumer Protection Law enacted in 1995, as well as its regulations promulgated in 1999, introduced product labeling standards and consumer rights to Nicaragua. While most U.S. products will likely meet Nicaraguan regulations by following U.S. guidelines, the following should be noted: the label must list product origin, contents, price, weight, production date, and expiration date. Proper use and risk information should also be provided. Although information is required to be in Spanish, as of mid-2002, Nicaragua does not enforce its language requirements. If the product is destined for the Atlantic coast area, however, English or the local indigenous language would be practical.

\section{Temporary Entry Provisions}

Items such as machinery, raw materials, components, and packaging materials may enter Nicaragua duty free. Firms located in approved free trade zone locations can conveniently import unfinished products for processing and re-export on a duty-free, in-bound basis. This same treatment is accorded to subcontractors of plants in free trade zones. Registered foreign investors are allowed to re-export equipment and machinery as well as to repatriate capital.

Special procedures apply for the short-term entry of goods (e.g., laptop computers, business samples, professional equipment, and exhibit materials). On entry, a deposit must be made with Nicaraguan Customs (Dirección General de Aduanas) equivalent to the tariffs and duties that would be paid for a permanent import of the same item. The Customs office determines that amount on the spot, which can be in excess of $20 \%$ of the value of the item. This deposit is returned when the item leaves the country (must be within six months of entry). It is possible to complete the paperwork and pay the deposit ahead of time, although this must be done in person at the Customs office (telephone 505-249-5719).

\section{Import Controls}

Imports require the following documentation: bill of lading (for land and maritime shipments), 
packing lists, airway bill (for air shipments), and invoice. Exports require an export certificate. Other documents may be required, depending on the product and destination.

Permits are required only for the importation of sugar. American exporters of food products should check with the Ministry of Agriculture concerning phytosanitary requirements. The government has established a mandatory registration for importers (RNI). Importers claim that the RNI creates additional costs, since they are now required to be cleared by several agencies that have nothing to do with the importer's commercial activities (i.e., the tax agency, Nicaraguan Customs, the electricity distribution company, and the ENITEL telephone company).

Few restrictions exist. The Ministry of Natural Resources and the Ministry of Agriculture regulate the use of agricultural chemicals. The import duties on a few items are so high (e.g., chicken parts have a $170 \%$ tariff) that imports may not be feasible.

Importers of fresh produce, livestock, and food products should check with the Ministry of Agriculture for the latest phytosanitary regulations. The Ministry of Health has decided to ask importers to submit analyses of transgenic products used to manufacture food imported into the country. The government claims this information is for informational purposes only.

\section{Export Controls}

All export documentation can be processed at the government's “one-stop" export center, CETREX. Any prospective exporter can register within minutes and register export transactions immediately.

Few export controls remain in place. The Nicaraguan government regulations currently prohibit the export of larval shrimp and reproductive-phase and under-sized lobsters, and control the export of wildlife products. The export of capital goods as scrap no longer requires the permission of MIFIC. The National Forestry Institute (INAFOR) is the entity that controls wood inventories and authorizes the export of precious woods. A CITES (Convention on International Trade in Endangered Species) permit is required for the export of wild and precious species, including precious woods.

\section{Free Trade Zones / Warehouses}

The free trade zone regime has grown rapidly since 1997. The state-owned Free Trade Zone Corporation (CZF) hosts 15 companies at the Las Mercedes Industrial Free Zone, located near Managua's international airport. Additionally, the CZF has, under its umbrella, 20 companies that are run as self-managed free trade zones (ZOFAS) in diverse provinces of the country. There are seven privately owned free trade zones authorized; two of them are still under construction.

\section{Membership in Free Trade Agreements}

Nicaragua is a member of the Central American Common Market (CACM). As such, the majority of goods produced in these nations are imported duty free. The CACM member nations signed a free trade agreement with the Dominican Republic in 1998 and are currently negotiating an agreement with the Southern Cone nations of South America (MERCOSUR). Nicaragua has negotiated free trade agreements with Mexico, Chile, Panama, and the Dominican Republic. Only the accord with Mexico is functional. Currently, Nicaragua and some of its Central American neighbors are conducting trade workshops with the United States, laying the framework for a prospective Central America-United States free trade agreement. Nicaragua is a Caribbean Basin Initiative beneficiary; the country is not a beneficiary of the U.S. Generalized System of Preferences (GSP).

\section{Investment Climate in Brief}

- The Foreign Investment Law, Law No. 344 of 2000 assures that foreign and domestic investment receive the same treatment; eliminates the need to sign an investment contract; abolishes the foreign investment committee; eliminates restrictions on the way in which foreign capital can enter the country, and; recognizes the investor's right to own property and use it as he wishes, and in the case of a declaration of eminent domain, receive proper indemnification. 
- Investors freely repatriate profits through banks. The Embassy knows of no instances in which profit repatriation has been a problem.

- Dollars are freely available through a legal parallel exchange market operated by local financial institutions. The Embassy is aware of no instances where an investor has been unable to obtain dollars.

- Difficulty in resolving commercial disputes in Nicaragua, particularly the enforcement of contracts, is a serious obstacle to investment. On the whole, the legal system is cumbersome and often corrupt or subject to outside pressures.

- Because of the history of property invasions and confiscations, determining the legal owner of real property can be very difficult. Often, more than one person has seemingly valid title documents.

- In the fishing industry, investment and employment commitments have been made conditions for receiving licenses.

- Foreign and domestic private entities or individuals may establish and own business enterprises and profit-making activities. Local law grants the right to freely establish, acquire, and dispose of virtually any type of business interest or property, with the exception of those sectors where government monopoly is established by law. The Embassy is aware of no instances where private enterprises were not treated on equal footing with public enterprises with respect to access to markets, credit, and other business operations.

- Despite significant streamlining in recent years, Nicaragua's legal and regulatory framework remains cumbersome. The rules are not fully transparent, and much business is still conducted on a "who you know" basis. Lack of reliable dispute resolution mechanisms (whether judicial or administrative) complicates even relatively minor disputes with the authorities or local business contacts.
- Nicaragua's capital base is small and the financial system has limited assets.

- Political violence is not prevalent in Nicaragua. There have been no recent instances of political violence targeted against foreign business operations.

- The U.S. Overseas Private Investment Corporation offers financing for American investments in Nicaragua. It can also provide political risk, expropriation, and inconvertibility insurance. The Nicaraguan private sector is eligible for the U.S. Export-Import Bank's shortand medium-term programs to finance U.S. exports. Nicaragua is a member of the World Bank's Multilateral Investment Guarantee Agency (MIGA).

- Nicaragua's labor force, estimated at 1.9 million workers, is rural-based and largely unskilled. An estimated $43 \%$ of the employed population is working in the agricultural sector, $15 \%$ in manufacturing, and $42 \%$ in services.

\section{Business Customs}

\section{Travel Advisory and Visas}

No Department of State travel advisory is in effect for Nicaragua. However, travelers are encouraged to review the latest U.S. Department of State's consular information sheet on Nicaragua prior to initiating travel. American citizens do not need to obtain a visa for visits of less than 90 days. Tourist cards are required and may be obtained upon entry for US\$5.00. Visas are required for stays of 90 days or longer. There is a departure tax of US\$33.00.

Individuals wishing to establish themselves in the country must request a resident visa from the Office of Immigration. Several investors have been deported because they were deemed to be "working" using a visitor's visa, even though they had declared the purpose of their visit as "business" on entry into Nicaragua. As investors move towards solidifying their investments (preparing to open bank accounts, registering their investment at MIFIC, etc.), they should consult with the Nicaraguan Immigration Service to determine if they need to file for residency or obtain a type of work permit. 


\section{Business Infrastructure}

Although business customs are informal, the use of coats and ties or business suits is common. Delays are common in the start of scheduled appointments, and flexibility in business travel is recommended. Business lunches are lengthy, and most Nicaraguan executives are unavailable between 12:00 p.m. and 2:00 p.m.

The official language of Nicaragua is Spanish, but English is spoken by some in business and government circles, as well as on the Atlantic coast.

Managua International Airport constructed separate cargo facilities in 1995 . The main cargo carriers are Fine Airlines (based in Miami) and TACA Airlines (based in Costa Rica). UPS has joined forces with Challenge Air Cargo, and now averages six flights a week. In addition, most passenger airlines, including American and Continental, maintain some cargo capacity. A 3,500 cubic foot cold storage facility at the airport opened in 1996. The airport is currently in the process of doubling its passenger traffic capacity. It is expected to handle 1.4 million passengers per year after 2002 .

Nicaragua's communication system (telephone, telex, etc.) is being updated through the installation of fiber optic technology. Telephone density is three telephones per 100 inhabitants. Public phones operate all over the country. Cellular phones are available in Nicaragua with coverage over the entire Pacific Coast. Approximate cellular-to-cellular and cellular-to-landline cost per minute is 26 U.S. cents. A separate, very limited cellular service is offered on the Atlantic Coast. A PCS cellular license has been auctioned off. When operational, this bandwidth should have countrywide coverage. Communication with the United States is readily available; AT\&T, Sprint, and MCI offer direct service between the United States and Nicaragua.

Hotels charge US\$50.00 to US\$220.00 per night for a single-room range (not including the $15 \%$ value-added tax). There are few first-class apartments in Nicaragua. There is an ample supply of houses for rent. The cost varies greatly, depending on the quality of construction and location of the neighborhood.
Numerous restaurants in Managua offer first-class international and continental cuisine. Outside of the capital, the local diet consists of chicken, beef, fish, rice, beans, plantains, and potatoes.

Health conditions in Nicaragua are improving, although it remains a tropical country with the presence of malaria, dengue fever, and a variety of gastro-intestinal disorders. Sanitary practices should be carefully followed, particularly outside of Managua. Typhoid, polio, tetanus, diphtheria and gamma globulin (or Hepatitis A) vaccinations are recommended prior to leaving the United States, particularly for extended stays. Local hospitals are adequate for basic care. However, they fall short of U.S. standards and are not recommended for serious conditions. There are a modest number of U.S.-trained physicians. There are many pharmacies with adequate supplies of most commonly used medications.

\section{Useful Web Sites}

\section{NICARAGUA:}

- US Embassy Managua http://usembassy.state.gov/managua

- Nicaraguan Center for Export and Investment (CEI) http://www.cei.org.ni

- Ministry of Agriculture http://www.magfor.gob.ni

- CETREX http://www.cetrex.com.ni

- United Government-Nicaraguan Government Links http://www.unitedgovt.com/nicaragua.html

\section{UNITED STATES:}

- USDA Foreign Agricultural Service http://www.fas.usda.gov

- US Export Programs Guide http://infoserv2.ita.doc.gov/ticwebsite/tic.nsf/ AF34FA880278BDD5825690D00656C6F/ F69FDCF72B7713B58525691900746F18?Open Document 
- Internet Guide to Trade Leads

http://infoserv2.ita.doc/gov/ticwebsite/tic.nsf/

504ca249c786e20f85256284006da7ab/

ef7db94aef24919885266470049c1cd?OpenDocu

ment

- US Trade Finance Resources

http://infoserv2.ita.doc.gov/ticwebsite/tic.nsf/

AF34FA880278BDD5825690D00656C6F/

F69FDCF72B7713B58525691900746F18?Open

Document

- Basic Guide to Exporting

http://www.unzco.com/basicguide/index.html

\section{HEMISPHERIC:}

- Hemispheric Guide on Customs Procedures

http://alca-ftaa.iadb.org/hgcp_eng.htm

- Hemispheric Trade and Tariff Database

http://alca-ftaa.iadb.org/eng/ngmadb_e.htm 